\title{
MANAGING SUSTAINABLE INFRASTRUCTURE AND URBAN DEVELOPMENT: SHAPING A BETTER FUTURE FOR ASEAN
}

\author{
Mohammed Ali Berawi ${ }^{1^{*}}$ \\ ${ }^{1}$ Faculty of Engineering, Universitas Indonesia, Kampus UI Depok, Depok 16424, Indonesia
}

The Association of Southeast Asian Nations (ASEAN) has assigned a high priority to supporting regional development in Southeast Asia. As the ASEAN countries continue to urbanize rapidly, shaping sustainable cities becomes increasingly important, particularly with regard to the development of adequate infrastructures. Infrastructure is a critical element in connectivity within the ASEAN region, and with significant growth in ASEAN trade and investment, productivity and growth must be sustained and enhanced by investing more resources in urban infrastructure.

The growth and diversification of the ASEAN economy depends on financing and developing long-term infrastructures, with adequate planning, funding, building and operation of urban infrastructure mechanisms for the development of sustainable cities. Urban sustainability provides opportunities for capital investment through urban renewal and infrastructure improvements. Public-private partnerships can be used to accelerate city development by attracting private sector funding for the development of sustainable infrastructure.

Urban infrastructure encompasses the essential facilities, services, and social structures that ensure the productivity and well-being of cities and communities. Transport, housing, telecommunication, energy, and water infrastructure are among the basic infrastructures that are necessary for urban development and growth. Societal wellbeing also depends on other infrastructures, including various forms of social infrastructure. Meeting the challenges of city development, from traffic jams and inefficient buildings to social inequality and poverty, demands innovative urban planning and technological and governance models that enable cities to become more sustainable. It is clear that the trend toward accelerated urbanization creates greater opportunities for economic growth and improving quality of life, and urban ecosystems and green infrastructure development are important assets for the sustainable city.

\section{Advancing Urban Infrastructure Development}

In this special edition of IJTech, we are pleased to present twenty two selected papers from the first CSID AUN-SCUD International Conference on Sustainable Infrastructure and Urban Development 2018 and the Scholar Summit 2017 on shaping a better world by enhancing research capacity and contributions to address national, regional, and global challenges. The conferences were organized by the ASEAN University Network (AUN) for Sustainable Cities and Urban Development, the Center for Sustainable Infrastructure Development (CSID), and Universitas Indonesia. The event attracted papers and presentations from ASEAN countries and from the United Kingdom, the United States, China, and elsewhere. As a medium for best practice and knowledge exchange, the CSID AUN-SCUD conference discusses sustainable development issues and how governments, academics, and industry can contribute to shaping a better future for society.

\footnotetext{
*Corresponding author's email: maberawi@eng.ui.ac.id, Tel. +62-21-7270029, Fax. +62-21-7270028 Permalink/DOI: https://doi.org/10.14716/ijtech.v9i7.2731
} 
The first paper, by D.T. Doan, A. Ghaffarianhoseini, N. Naismith, T. Zhang, J. Tookey, and A.H. Ghaffarianhoseini, examines the relationship between adoption of Building Information Modelling (BIM) and Green Star certification in providing substantial environmental benefits for construction projects. The authors argue that their findings provide baseline information for effective strategic development of BIM and Green Star.

The next paper, written by F. Ali, D.L. Lestari, M.D. Putri, and K.N. Azmi, examines the characteristics and patterns of clean water consumption at the pilot household scale. Given the limited availability of clean water, the authors argue that six major elements of household water usage offer delta water saving potential: bathing, teeth brushing, hand and face washing, dish washing, clothes washing, and floor cleaning.

The third paper, written by X. He, Z. Yang, K. Zhang, P. Yang, and S. Zhang, investigates spatial distribution patterns in the catering trade in Nanchang based on internet commentary. The authors argue that network data analysis of the catering industry's spatial distribution and influencing factors can inform city planning and urban development.

The fourth paper, written by M.A. Berawi, N. Suwartha, K. Kurnia, Gunawan, P. Miraj, and A.R.B. Berawi, proposes a predictive model of land market values in the context of transportation infrastructure development and investigate correlations among factors that affect land price. They argue that the price of land is affected by land shape, economy of residents, distance to station, and property age.

The fifth paper, written by C. Xia and Y. Li, evaluates ecological construction in Kunming using the Driver-Pressure-State-Impact-Response (DPSIR) model. The authors argue that the potential value of ecological construction enterprises and technology should be fully explored, and further suggest that government should transform ecology-oriented into ecological cooperation, cultivating technical talents and using environmental technologies to develop ecological industries.

The next paper, written by H. Mardhotillah and A. Gamal, investigates the segregation and gentrification of informal settlements in the city center. The authors argue that differences in expertise among residents of formal and informal settlements create socioeconomic inequalities and physical boundaries because of the differing economic growth rates of formal and informal settlements.

The seventh paper, written by P.J. Sankowska, describes the European smart government approach to building sustainable and secure cities for the future. The author highlights eight key areas of smart technology that can enhance sustainable city development, including municipal digitalization and innovation for city connectivity, cooperation, and communication.

The eighth paper, written by A.N. Zahra and Herlily, assesses the idea of reclaiming the street for pedestrians as a sustainable city approach. They argue that encouraging public transportation and walking and promoting the street as a public space can reduce congestion and impact positively on the environment to ensure a livable and sustainable city.

The next paper, written by $\mathrm{H}$. Ullah and A. Datta, investigates the effect of water-saving technologies on the growth, yield, and water-saving potential of lowland rice. As compared to the traditional method, the highest water-saving potential $(62 \%)$ was observed at $-30 \mathrm{kPa}$, falling by $24-82 \%$ for other soil moisture levels.

The tenth paper, written by A.F. Satwikasari, L. Hakim, and L. Prayogi, investigates thermal environment quality using voids and indoor gardens as a passive design strategy for 
sustainable and healthy living. The authors argue that a modified room with a void and indoor garden has a significant effect on thermal comfort.

The eleventh paper, written by E.D. Miro, J. L. Martin, L. Lopez, J. Sescon, C. Oracion, and J. Loanzon, describes a supply chain profile for the largest city-wide implementation of the ACED Blueplate Centralized Kitchen (ABCK) model and propose that this offers a viable template for efficient and effective large-scale school catering operations.

The next paper, written by R.T. Hakim and R.D. Kusumastuti, proposes a model for determining relief warehouse location using the analytic hierarchy process. They claim that the proposed model can be applied to the preparedness stage of the disaster management cycle and can be combined in the response stage with the facility location model and the vehicle routing model.

The thirteenth paper, written by B.A. Kayan, I.A. Halim, and N.S. Mahmud, investigates the applicability of green maintenance in assessing low carbon repair of laterite stone structures based on their embodied carbon expenditure. The authors argue that the quality of repair (workmanship), selection of materials to deal with the area of deterioration and material durability are the other main variables to be considered when selecting the most sustainable repair and maintenance.

The fourteenth paper, written by N.A.T. Nguyen, P. Sudjono, G.T. Kusuma, A.Y. Gunawan, and B.S. Muntalif, investigates conservative solute transport from soil to runoff flow in steeply sloped areas. They argue that overland flow is dominated by the saturation excess mechanism, with the lowest percentage of overland flow generated by natural grass plots as compared to removal grass and without grass plots.

The next paper, written by M. Magista, B.L. Dorra, and T.Y. Pean, examines the potential of gamification for improving schoolchildren's waste management practices. They discuss environmental gamification as an innovative means of improving schoolchildren's householdlevel waste management behaviors.

The sixteenth paper, written by S. Luziani and B. Paramita, assesses land ecological enhancement planning for the design of sustainable areas. They contend that urban development proposals should consider basic green areas, public green areas, habitat conservation, land revitalization, micro climate, and productive land.

The next paper, written by S. Jarupathirun and M.D. Gennaro, investigates work satisfaction factors and their influence on employee turnover. The authors argue that employees' rankings of various measures of satisfaction include remuneration, work achievement, and working conditions.

The eighteenth paper, written by M.A. Berawi, A. Nabila, Gunawan, P. Miraj, H.A. Rahman, and A.R.B. Berawi, examines life cycle cost analysis and public-private partnership in the development of Walini city as a technology park. The authors refer to five main areas to be developed in the City of Walini to produce optimal IRR value: industrial, residential, education, commercial, and research and development zones.

The nineteenth paper, written by P. Antwi-Afari, D.G. Owusu-Manu, E. Pärn and D.J Edwards, investigates the challenges and expectations of innovating quantity surveyors and quantity surveying firms. The authors emphasize the need for regulations and policies that enable the profession to ensure accountability, innovation, and robust continuing professional development.

The twentieth paper, written by G.G.R Gunadi, A.I. Siswantara, and Budiarso, compares turbulence models of the air flow in crossflow turbines. The authors argue that the RNG k- $\varepsilon$ 
turbulence model produces better results in terms of average pressure and velocity distribution measurements such as kinetic energy, dissipation rate, and effective viscosity.

The next paper, written by E. Kusrini, D. Supramono, V. Degirmenci, S. Pranata, A.A. Bawono, and F.N. Ani, describes the production and quality enhancement of pyrolysis oil made from palm empty fruit bunches (EFB). The authors argue that high-density polyethylene (HDPE) waste contributes to the decline in pyrolysis oil and the increase in gas production.

Finally, the last paper, written by R.M. Woodhead, explores the idea of what a smart city could be and how we contribute towards a measurable notion of city progress. The author argues that smart city innovation requires a paradigm shifting from transactional thinking based around notions of servant leaders and citizens as 'customers'. Indeed, it needs everyone in a city, whether a local government employee or resident, to see themselves as 'citizens' with a stake in making their city a great place to live, work and play.

I hope that this edition of IJTech will offer some new insights into our research. I will be pleased to address any comments or queries you may have about the direction and content of IJTech, and I invite you to join us in this venture by sending your work for consideration.

With warmest regards from Jakarta,

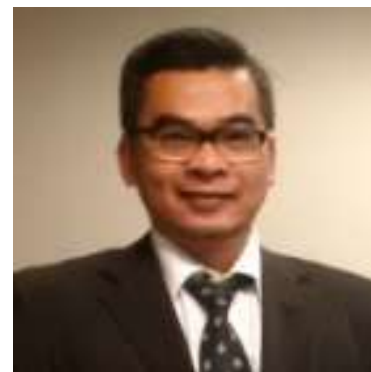

Dr. Mohammed Ali Berawi

Editor in Chief 